\title{
Managing Nutsedge and Stunt Nematode in Pepper with Reduced Methyl Bromide plus Chloropicrin Rates under Virtually Impermeable Films
}

\author{
Bielinski M. Santos ${ }^{1}$, James P. Gilreath ${ }^{2}$, and Timothy N. Motis ${ }^{3}$
}

AdDITIONAL INDEX wORDs. Cyperus, Tylenchorbynchus, low-density polyethylene mulch, fumigant retention, bell pepper

Summary. Two field trials were conducted to determine the effect of reduced methyl bromide plus chloropicrin $(\mathrm{MBr}+\mathrm{Pic} 67: 33 \mathrm{v} / \mathrm{v})$ rates applied under two types of virtually impermeable films (VIF) on nutsedges (Cyperus spp.) and stunt nematode (Tylenchorbynchus spp.) control, and bell pepper (Capsicum annuum) crop yield. A split-plot design with six replications was established, with $\mathrm{MBr}+$ Pic rates in the main plots and mulch types as subplots. $\mathrm{MBr}+\mathrm{Pic}$ rates were 0 , 88,175 , and $350 \mathrm{lb} /$ acre. Mulch types were low-density polyethylene (LDPE) mulch, Hytibar VIF, and Bromostop VIF. Results showed that there were no differences on weed and nematode control, and bell pepper fruit yield between the two types of VIF. Two exponential models characterized the nutsedge responses to $\mathrm{MBr}+\mathrm{Pic}$ rates with LDPE mulch and VIF, with weed densities declining as $\mathrm{MBr}+\mathrm{Pic}$ rates increased. Reducing $\mathrm{MBr}+\mathrm{Pic}$ rates by one-half (175 lb/acre) under VIF provided similar nutsedge control as the full-rate $(350 \mathrm{lb} / \mathrm{acre})$ with LDPE mulch. Similar results were observed with stunt nematode, where the most effective control occurred with VIF. Bell pepper yield with LDPE mulch responded linearly to increased $\mathrm{MBr}+\mathrm{Pic}$ rates. However, a logarithmic model described the response of pepper yields to the fumigant rates under VIF. The application rate of this fumigant could be effectively reduced to $25 \%$ of the commercial rate $(350 \mathrm{lb} /$ acre $)$ under either VIF, without causing significant bell pepper yield losses.

I n Florida, bell pepper fields are commonly infested by weeds and nematodes. Mixed stands of nutsedges (Cyperus rotundus and C. esculentus) and high populations of stunt nematode are regularly found. When nutsedges are allowed to interfere with bell pepper, reported yield losses have been substantial (Morales-Payan et al., 1998; Motis et al., 2001). MBr alone, or in combination with Pic, has been the soil fumigant of choice since the early 1970s (Overman and Martin, 1978), because of its ease of use and high efficacy under a wide range of conditions. It is typically shank-injected at $350 \mathrm{lb} /$ acre to a soil depth of 10 inches into raised beds that are simultaneously covered with LDPE mulch.

Gulf Coast Research and Education Center, University of Florida, 5007 60th St. E., Bradenton, FL 34203.

Research supported by the Florida Agricultural Experiment Station and approved as Journal Series R-10545.

${ }^{1}$ Research Associate; e-mail: bmsantos@ifas. ufl.edu

${ }^{2}$ Professor.

${ }^{3}$ Former Research Associate.
Standard LDPE is inexpensive and easy to use, but it is highly permeable to $\mathrm{MBr}$ (Gamliel et al., 1998a, 1998b; Papiernik and Yates, 2001; Williams et al., 1999; Yates et al., 1996a, 1996b). MBr has been classified as a substance that contributes to depletion of stratospheric ozone. Consequently, a complete phase-out of the use and production of $\mathrm{MBr}$ in developed countries throughout the world is scheduled to occur by 2005 , with critical use exemptions permitted under the Montreal Protocol (U.S. Environmental Protection Agency, 1999). Critical use exemptions will be important for minor crops because a viable $\mathrm{MBr}$ alternative is not yet available. However, even if exemptions are

\begin{tabular}{|c|c|c|c|}
\hline \\
\hline $\begin{array}{l}\text { To convert } \\
\text { U.S. to SI, } \\
\text { multiply by }\end{array}$ & U.S. unit & SI unit & $\begin{array}{l}\text { To convert } \\
\text { SI to U.S., } \\
\text { multiply by }\end{array}$ \\
\hline 29.5735 & $\mathrm{fl} \mathrm{oz}$ & $\mathrm{mL}$ & 0.0338 \\
\hline 0.3048 & $\mathrm{ft}$ & $\mathrm{m}$ & 3.2808 \\
\hline 0.0929 & $\mathrm{ft}^{2}$ & $\mathrm{~m}^{2}$ & 10.7639 \\
\hline 2.5400 & inch(es) & $\mathrm{cm}$ & 0.3937 \\
\hline 16.3871 & inch $^{3}$ & $\mathrm{~cm}^{3}$ & 0.0610 \\
\hline 1.1209 & $\mathrm{lb} /$ acre & $\mathrm{kg} \cdot \mathrm{ha}^{-1}$ & 0.8922 \\
\hline
\end{tabular}


permitted, reduced rates of $\mathrm{MBr}$ may be needed to offset the rising cost of the fumigant and to reduce atmospheric emissions.

To obtain a high degree of pest control with a fumigant, it is necessary to maintain a sufficient quantity of fumigant gas in the soil long enough to reduce the population of pests (Gamliel et al., 1998b; Minuto et al., 1999). This might be accomplished by using low rates of $\mathrm{MBr}$ under VIF, which has become commercially available in recent years and is much more retentive of fumigant gasses than standard LDPE mulch (Papiernik and Yates, 2001). This type of film increases fumigant toxicity by increasing the duration of retention, which is caused by a barrier polymer, such as ethylene vinyl alcohol, placed between two layers of polyethylene (Papiernik and Yates, 2001).

Wang et al. (1997) determined that atmospheric emission of $\mathrm{MBr}$, when covered with polyethylene for $5 \mathrm{~d}$, declined from $64 \%$ of applied $\mathrm{MBr}$ with conventional LDPE mulch to about $38 \%$ with VIF. With the soil covered by VIF for more than $10 \mathrm{~d}$, only $1 \%$ to $3 \%$ of the MBrwas lost. This research was conducted to determine if reduced $\mathrm{MBr}$ plus Pic rates applied under VIF could provide the same extent of nutsedge and stunt nematode control and bell pepper crop yield as the commercially used $\mathrm{MBr}$ plus Pic rate under LDPE mulch.

\section{Materials and methods}

Experiments were conducted in Fall 2002 and Spring 2003 at the Gulf Coast Research and Education Center in Bradenton, Fla., on an EauGallie fine sand. A split-plot design with six replications was established, with $\mathrm{MBr}+$ Pic rates $0,88,175$, and 350 $\mathrm{lb} / \mathrm{acre}$ in the main plots and mulch types as subplots. Mulch types were LDPE (Pliant Corp., Schaumburg, Ill.) mulch, VIF by Hytibar (Klerk's Plastic, Hoogstraten, Belgium), and VIF by Bromostop (Industrial Plastica Monregalise, Mondovi, Italy).

Treatments were applied on 17 Sept. 2002 and 29 Jan. 2003. With all treatments, preplant fertilizer was broadcast and incorporated at rates of $50 \mathrm{lb} /$ acre nitrogen $(\mathrm{N}), 20 \mathrm{lb} /$ acre phosphorus $(\mathrm{P})$, and $40 \mathrm{lb} /$ acre potassium $(\mathrm{K})$; then prebeds were formed, pressed, and covered with their respective mulch. Beds were 32 inches wide at the base, 28 inches wide at the top, 8 inches high, and spaced 60 inches apart on centers. $\mathrm{MBr}+\operatorname{Pic}(67: 33 \mathrm{v} / \mathrm{v})$, was injected 6 to 8 inches deep into the finished bed using a N-propelled fumigation rig with three chisels per bed. Each chisel was spaced 12 inches apart. Immediately after $\mathrm{MBr}+\mathrm{Pic}$ application, each bed was covered with the appropriate film. Simultaneous with film covering, drip irrigation tubing (T-Tape Systems Intl., San Diego) was placed 1 inch deep down the bed center under the film. Irrigation was supplied daily via drip irrigation and additional $\mathrm{N}$ and $\mathrm{K}$ were supplied to the crop through the drip lines by daily injections of 2.5 and $2.0 \mathrm{lb} /$ acre of $\mathrm{N}$ and $\mathrm{K}$, respectively, resulting in total of 199.5 and 175 and $145 \mathrm{lb} /$ acre of each nutrient. 'Admiral' pepper seedlings were transplanted 14 inches apart within each of two rows per bed with 12 inches between rows 3 weeks after treatment. Plots were $60 \mathrm{ft}$ long and only the central $40 \mathrm{ft}$ were used for data collection. Foliar pesticides were applied as needed and following current grower practices (Maynard et al., 2003).

The population of nutsedge shoots on the top of each bed was counted at 8 weeks after transplanting. Stunt nematode populations were determined 14 weeks after transplanting by extracting soil samples with a soil probe 1 inch wide by 8 inches deep rom the rhizosphere of 8 to 10 tomato plants per plot, and the nematodes were separated from $100 \mathrm{~cm}^{3}$ soil using a standard sieving and centrifugation procedure(Jenkins, 1964). Marketable pepper fruits (mature, green or red) were harvested two to three times each season. Fruit weight for each harvest was determined and added to obtain season total marketable yield. Treatment and season effects were analyzed with analysis of variance $(P=0.05)$ and regression analyses were conducted to describe the relationship between $\mathrm{MBr}+\mathrm{Pic}$ rates and each variable (SAS Institute, 2000).

\section{Results and discussion}

There were no significant season by treatment interactions. Therefore, data from two seasons were combined for analysis. Nutsedge populations were affected by $\mathrm{MBr}+\mathrm{Pic}$ rates. However, there were no differences between the two types of VIF; thus, their values were averaged within each $\mathrm{MBr}+$ Pic level. Two negative exponential models (Fig. 1) characterized the weed responses to $\mathrm{MBr}+\mathrm{Pic}$ rates with LDPE mulch and $\operatorname{VIF}\left(\mathrm{y}=141.24 \mathrm{e}^{-0.0073 \mathrm{x}}\right.$ and $\mathrm{y}=$ $146.35 \mathrm{e}^{-0.0141 x}$, respectively). These equations indicated that nutsedge densities declined as $\mathrm{MBr}+\mathrm{Pic}$ rates

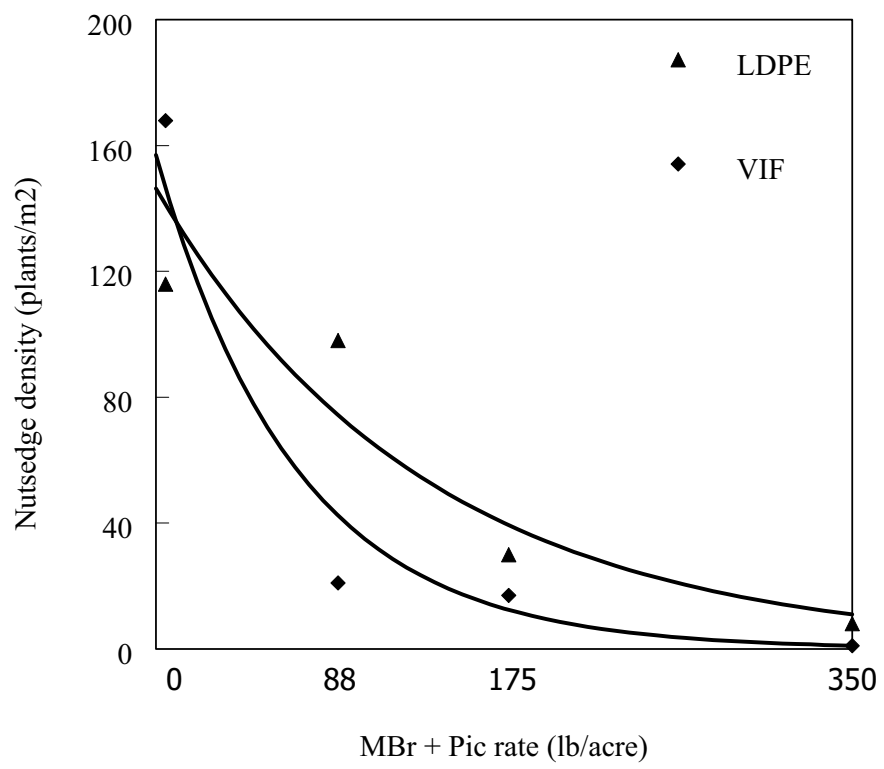

Fig. 1. Effects of methyl bromide plus chloropicrin $(\mathrm{MB}+$ Pic 67:33 v/v) rates under low-density polyethylene mulch (LDPE) and virtually impermeable film (VIF) on nutsedge densities in bell pepper at 8 weeks after transplanting in trials conducted during 2002 and 2003 in Bradenton, Fla. $\mathrm{MBr}+$ Pic rates were $0,88,175$, and $350 \mathrm{lb} /$ acre. The regression equations were $\mathrm{y}=141.24 \mathrm{e}^{-0.0073 \mathrm{x}}$ for LDPE mulch, and $\mathrm{y}=146.35 \mathrm{e}^{-0.0141 \mathrm{x}}$ for VIF $\left(1 \mathrm{~kg} \cdot \mathrm{ha}^{-1}=0.8922 \mathrm{lb} /\right.$ acre, 1 plant $/ \mathrm{m}^{2}=0.0929$ plant $\left./ \mathrm{ft}^{2}\right)$. 
increased. The weed density reduction was sharper with VIF than with LDPE mulch. Predicted values for $88 \mathrm{lb} /$ acre + Pic were 69.1 and 36.8 nutsedge plants $/ \mathrm{m}^{2}$ for LDPE mulch and VIF, respectively, which represented approximately a $47 \%$ reduction on weed density. When the $\mathrm{MBr}+\mathrm{Pic}$ rate was doubled to $175 \mathrm{lb} /$ acre, weed densities decreased to 33.8 and 9.2 plants $/ \mathrm{m}^{2}$ for LDPE mulch and VIF, respectively. These weed densities declined below 10 plants $/ \mathrm{m}^{2}$ for both mulch types when $\mathrm{MBr}+\mathrm{Pic}$ rates reached the commercially recommended $350 \mathrm{lb} /$ acre. The data indicated that reducing $\mathrm{MBr}$ + Pic rates by one-half ( $175 \mathrm{lb} / \mathrm{acre})$ under VIF provided similar nutsedge control as the full-rate $(350 \mathrm{lb} / \mathrm{acre})$ with LDPE mulch.

Stunt nematode control was not different with either VIF. Thus, their population means were combined for analysis. Regression models for LDPE mulch and VIF indicated that there was a sharp decline of nematode populations with the addition of $88 \mathrm{lb} /$ acre $\mathrm{MBr}+\mathrm{Pic}$, regardless of the mulch film (Fig. 2). However, stunt nematode control was more effective with VIF. Predicted values remained equal or lower than 10 juveniles $/ 100 \mathrm{~mL}$ soil when the fumigant was injected at rates between 88 and $350 \mathrm{lb} /$ acre.

Both mulch types and $\mathrm{MBr}+\mathrm{Pic}$ rates influenced marketable bell pepper yield. There were no significant differences between the two VIF; therefore their data were combined for analysis. Bell pepper yield with LDPE mulch responded linearly $(y=15.40+0.0195 x)$ to increased $\mathrm{MBr}+$ Pic rates (Fig. 3). However, a logarithmic model $[(\mathrm{y}=$ $12.58+2.16 \ln (\mathrm{x})]$ described the response of pepper yields to the fumigant rates under VIF. Based on orthogonal contrasts within each $\mathrm{MBr}+\mathrm{Pic}$ rate, there were no significant pepper yield differences between LDPE mulch and VIF, when the fumigant rates were 0 and $350 \mathrm{lb} /$ acre. On the other hand, there were 23 and $20 \%$ yield increases with VIF in comparison with LDPE mulch, when $\mathrm{MBr}+\mathrm{Pic}$ rates were 88 and $175 \mathrm{lb} /$ acre, respectively.

Within the range of $\mathrm{MBr}+\mathrm{Pic}$ rates tested, it appeared that the application rate of this fumigant could be effectively reduced to $25 \%$ of the commercial rate $(350 \mathrm{lb} /$ acre $)$ under either VIF, without causing significant bell pepper yield losses. These results are consistent with the nutsedge and

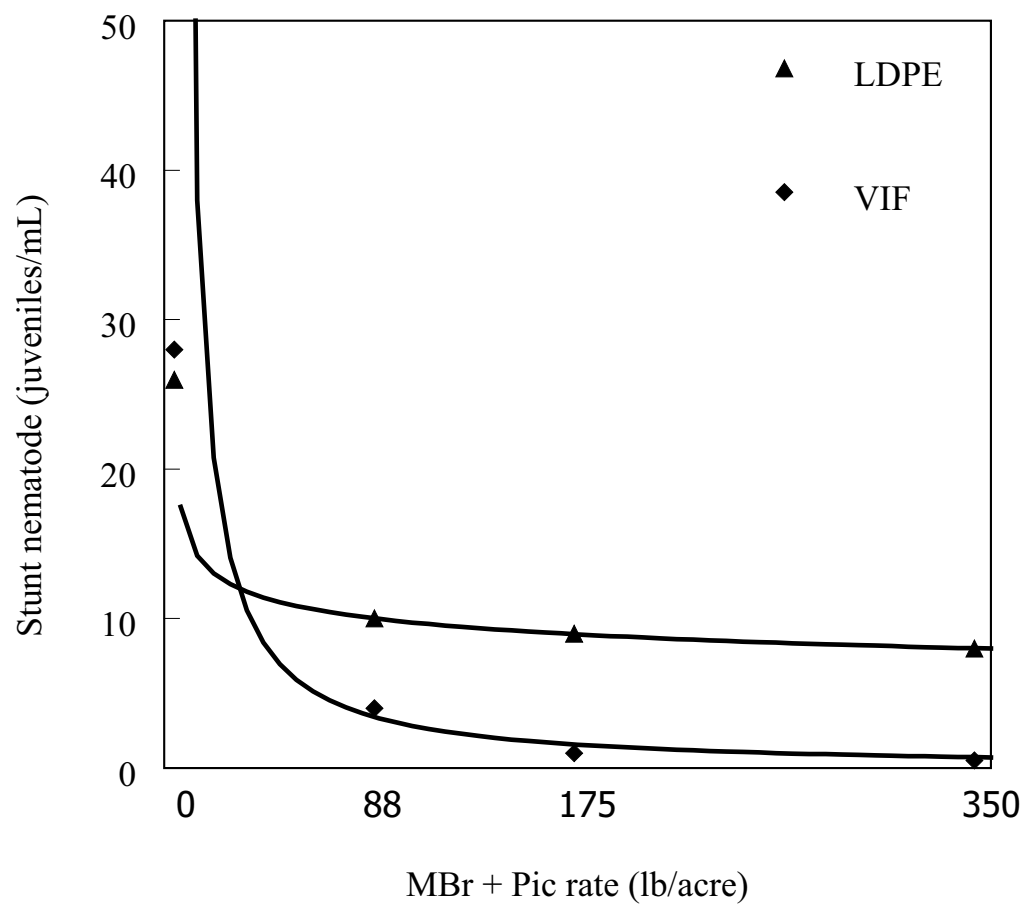

Fig. 2. Effects of methyl bromide plus chloropicrin $(M B+\operatorname{Pic} 67: 33 \mathrm{v} / \mathrm{v})$ rates under low-density polyethylene mulch (LDPE) and virtually impermeable film (VIF) on stunt nematode populations in bell pepper at 14 weeks after transplanting in trials conducted during 2002 and 2003 in Bradenton, Fla. $\mathrm{MBr}+\mathrm{Pic}$ rates were $0,88,175$, and $350 \mathrm{lb} / \mathrm{acre}$. The regression equations were $\mathrm{y}=20.96 \mathrm{x}^{-0.1610}$ for LDPE mulch, and $\mathrm{y}=556.61 \mathrm{x}^{-1.1112}$ for VIF $\left(1 \mathrm{~kg} \cdot \mathrm{ha}^{-1}=0.8922 \mathrm{lb} /\right.$ acre, 1 nema/100 $\left.\mathrm{mL}=283.2 \mathrm{nema} / \mathrm{ft}^{3}\right)$.

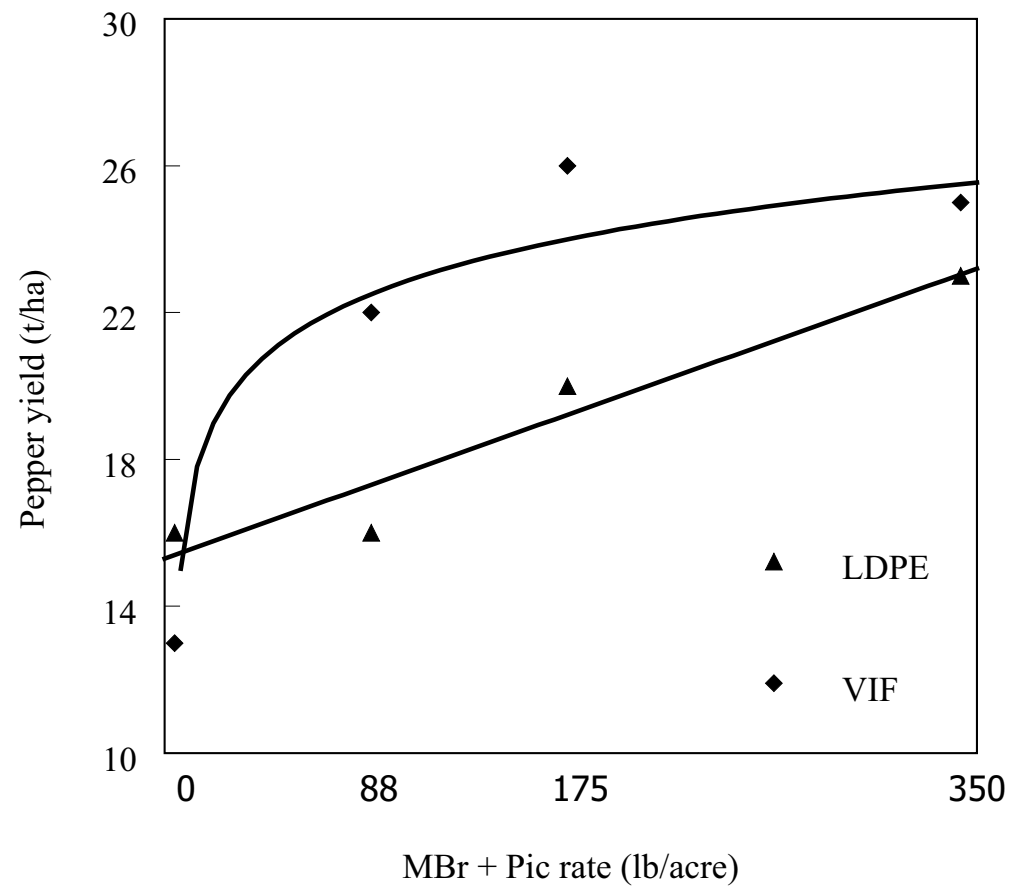

Fig. 3. Effects of methyl bromide plus chloropicrin $(M B+\operatorname{Pic} 67: 33 \mathrm{v} / \mathrm{v})$ rates under low-density polyethylene mulch (LDPE) and virtually impermeable film (VIF) on total bell pepper yield in trials conducted during 2002 and 2003 in Bradenton, Fla. $\mathrm{MBr}+\mathrm{Pic}$ rates were $0,88,175$, and $350 \mathrm{lb} /$ acre. The regression equations were $y=15.40+0.0195 x$ for $\mathrm{LDPE}$ mulch, and $=12.58+2.16$ $\ln (\mathrm{x})$ for VIF $\left(1 \mathrm{~kg} \cdot \mathrm{ha}^{-1}=0.8922 \mathrm{lb} / \mathrm{acre}, 1 \mathrm{t} \cdot \mathrm{ha}^{-1}=0.4461 \mathrm{ton} /\right.$ acre. 
stunt nematode control data presented herein and suggested that effective management of these pests can be obtained at a reduced $\mathrm{MBr}+\mathrm{Pic}$ rate applied under VIF. Gilreath et al. (2004) discussed similar results with other VIF brands in bell pepper. From the practical standpoint, bell pepper growers could plan applying less $\mathrm{MBr}+\mathrm{Pic}$, if VIF is utilized as part of a strategy to manage soilborne pests and to reduce atmospheric emissions.

\section{Literature cited}

Gamliel, A., A. Grinstein, M. Beniches, J. Katan, J. Fritsch, and P. Ducom. 1998a. Permeability of plastic films to methyl bromide: A comparative laboratory study. Pesticide Sci. 53:141-148.

Gamliel, A., A. Grinstein, L. Klein, Y. Cohen, and J. Katan. 1998b. Permeability of plastic films to methyl bromide: Field study. Crop Protection 17:241-248.

Gilreath, J.P., T.N. Motis, and B.M. Santos. 2005. Cyperus spp. control with reduced methyl bromide plus chloropicrin rates under virtually impermeable films in pepper. Crop Protection 24:(in press).

Jenkins, W.R. 1964. A rapid centrifugal-flotation technique for separating nematodes from soil. Plant Dis. Rptr. 48:692.
Maynard, D.N., G.J. Hochmuth, C.S. Vavrina, W.M. Stall, T.A. Kucharek, S.E. Webb, T.G. Taylor, S.A. Smith, E.H. Simonne, and S.M. Olson. 2003. Pepper production in Florida, p. 223-232. In: S.M. Olson and E.H. Simonne (eds.). Vegetable production guide for Florida. Inst. Food Agr. Sci. Publ., Gainesville, Fla.

Minuto, A., A. Gilardi, M.L. Gullino, and A. Garibaldi. 1999. Reduced dosages of methyl bromide applied under gasimpermeable plastic films for controlling soilborne pathogens of vegetable crops. Crop Protection 18:365-371.

Morales-Payan, J.P., B.M. Santos, W.M. Stall, and T.A. Bewick. 1998. Interference of purple nutsedge (Cyperus rotundus) population densities on bell pepper (Capsicum annuиm) yield as influenced by nitrogen. Weed Technol. 12:230-234.

Motis, T.N., S.J. Locascio, and J.P. Gilreath. 2001. Yellow nutsedge interference effects on fruit weight of polyethylene-mulched bell pepper. Proc. Fla. State Hort. Sci. 114:268-271.

Overman, A.J. and F.G. Martin. 1978. A survey of soil and crop management practices in the Florida tomato industry. Proc. Fla. State Hort. Soc. 91:294-297.

Papiernik, S.K. and S.R. Yates. 2001. Transport of fumigant compounds through HDPE and virtually impermeable films. Proc. Annu. Intl. Res. Conf. Methyl Bromide Alternatives and Emissions Reductions 10:16 (Abstr.).
SAS Institute. 2000. SAS/Stat user's guide. Version 8.1. SAS Inst., Cary, N.C.

U.S. Environmental Protection Agency. 1999. Protection of stratospheric ozone: Incorporation of Montreal protocol adjustment for a 1999 interim reduction in Class I, Group VI controlled substances. Federal Register 64:29240-29245.

Wang, D., S.R. Yates, F.F. Ernst, J. Gan, and W.A. Jury, W.A. 1997. Reducing methyl bromide emission with a high barrier plastic film and reduced dosage. Environ. Sci. Technol. 31:3686-3691.

Williams J., N.Y. Wang, and R.J. Cicerone. 1999. Methyl bromide emissions from agricultural field fumigations in California. J. Geophysical Res.-Atmospheres 104:30087-30096.

Yates, S.R., F.F. Ernst, J. Gan, F. Gao, and M.V. Yates. 1996a. Methyl bromide emissions from a covered field. 2. Volatilization. J. Environ. Quality 25:192-202.

Yates, S.R., J. Gan, F.F. Ernst, A. Mutziger, and M.V. Yates. 1996b. Methyl bromide emissions from a covered field. 1. Experimental conditions and degradation in soil. J. Environ. Quality 25:184-192. 